\title{
Challenges and Measures of Ideological and Political Work in Colleges and Universities in the Network Era
}

\author{
Na Xu*, Miao Liu \\ Guang Zhou Huashang College, Studnt's Affairs Division Zengcheng, Guangzhou 511300, China \\ ${ }^{1} \mathrm{Na} \mathrm{Xu}(1982.10)$, Female, Lecturer, Master degree, Main research is about ideological and political education, educational \\ information management.
}

${ }^{2}$ Miao Liu(1984.08), Female, Lecturer, Master degree, Main research is about ideological and political education, educational information management.

\begin{abstract}
To explore the challenges faced by the ideological and political work in Colleges and universities in the network era, this paper expounds the problems in the ideological and political work in Colleges and universities in the network era by reading literature and combining with theoretical knowledge, and puts forward solutions according to the problems for the reference of relevant personnel.
\end{abstract}

Key words: Network era; Ideological and political education in Colleges and universities; Challenge

Publication date: April, 2021; Publication online: 30 April, 2021

*Corresponding author: $\mathrm{Na}$ Xu, loumanxiaoxuanxuan@163.com

\section{Introduction}

In 2019, general secretary Xi Jinping led a university ideological and political conference, and put forward new requirements for school ideological and political education at the meeting. This shows that the importance of Ideological and political work in social development. Zhao Sichuan ${ }^{[1]}$ suggested that in the new era, there are three problems in the reform of the supply and demand side of Ideological and political courses in Colleges and universities, namely, the level of professional quality of the educational subjects. Therefore, it is proposed to cultivate the professional ethics of the professional subject and enhance the professionalism of the professional subject. By analyzing the needs of students, the teaching content of Ideological and political course should be improved, and the supply form should be reformed in an innovative way to meet the needs of the development of the new era; Liu Zefeng ${ }^{[2]}$ and others proposed that the supply mode of Ideological and political courses in Colleges and universities can be improved from five aspects, and the primary task of building a professional communication team is to grasp the communication content in the communication process, expand innovative communication channels, conduct market research, and study the communication objects, so as to improve the communication effect; Yu Yongmei ${ }^{[3]}$ and others also pointed out that when deepening the supply side reform, we need to adhere to the correct political direction and reform policy, give full play to the role of Ideological and political education in Colleges and universities, improve the ideological and political education of college students, reasonably integrate the teaching content and students' needs, realize the political transformation of Ideological and political education, strengthen the self-construction of teachers, and combine theory with practice to strengthen the ideological and political education. The role of Ideological and political education in Colleges and universities should be taught to students in an innovative way to improve their interest in learning; Feng Jie ${ }^{[4]}$ and others pointed out that the ideological and political education in Colleges and universities has the characteristics of guidance, accuracy and efficiency. In order to break through the current bottleneck, we need to carry out continuous reform and innovation.

2 Challenges of Ideological and Political Work in Colleges and Universities in the Internet Age

2.1 Information expansion brought by Internet 
The Internet is full of all kinds of information and data, which not only broaden the horizon of knowledge and provide convenience for learning, but also affect the mental health of modern college students. In particular, modern college students have established the orthodox value of life through traditional Chinese theoretical education. It can be said that the main countries of the Internet are dominated by western countries, and their ideology affects many people. Western countries have a lot to learn, but it is undeniable that there are huge differences between Chinese and western ideological values. Under the background of open network, students' brains are suddenly released. They gradually open themselves up, let themselves play, and explore the "world" they haven't touched. At this time, egoism, hedonism and other nonmainstream, some non-positive thoughts gradually fill the minds of college students and social people, leading to problems in college students' ideological values. In addition, there are many vulgar, pornographic, violent and other contents on the Internet, all of which have a profound impact on the thoughts and behaviors of modern college students. For the University's ideological and political management department, how to deal with the network information is also a major challenge.

\subsection{Contemporary young people are addicted to the Internet}

The virtual nature of the Internet has become a haven for many college students, especially modern college students are facing the pressure of life, learning and future employment. Like introverts and timids, they are comfortable on the Internet. When encountering some unsatisfied family or school violence and other unfortunate events, students will find solutions on the Internet, and escape from the current problems through the stimulation of the Internet. If students can not get rid of the satisfactory inner pleasure, it will only lead to students' long-term infatuation and immersion in the Internet world, and become more inseparable from the Internet Disappointed, the network is like losing soul, unable to communicate with people in real life, affecting work.

\subsection{The erosion of network culture}

Network environment is very open, information knowledge is also very comprehensive, can share a lot of information. In the network, no one knows their identity, and the dialogue between people seems to get rid of the obstacles and embarrassment in real life. In the network, equal communication and courage to express are very important. At the same time, under the information background of the mutual infiltration of Chinese and Western cultures in this open era, college students may be exposed to many new ideas and new ideas, but their ability of expression seems to be enhanced. However, in an open environment, many college students often suffer from malicious agitation and infiltration of bad Galaxy due to their shallow life experience, which leads to rebellious thoughts.

3 Ways to carry out ideological and political work in Colleges and universities in the Internet Age

3.1 Provide appropriate guidance and guidance to enable students to have the ability to apply new media programs In the new media era, in order to greatly improve students' Ideological and political literacy and further improve the effectiveness of Ideological and political education, it is necessary to greatly improve students' ability to use new media and the ability to use new media technology. In the process of Ideological and political education, we should correctly guide students to choose an effective and highquality platform, guide students to acquire knowledge from a formal and effective platform, and inform students of the importance of using the correct information platform, so as to enrich the education content and improve students' learning effect. In the teaching process of Ideological and political courses, schools and teachers should fully reflect their role in the education process, and focus on teaching and promoting new media application skills. In the actual course, students must have the necessary new media application skills, at the same time, they must carry out in-depth and detailed analysis of all the information of new media, so as to enable students to have the concept of right and wrong, as well as the ability of analysis and judgment. Through continuous practice and practice, students can distinguish between true and false in complex information, and make a more scientific and reasonable judgment, so as not to have a negative impact on students' Outlook on life, world outlook and values, and can reasonably, completely and scientifically build their own network information true and false identification system. At the same time, it can reduce the infringement of network bad information on students, avoid the influence of bad information on their own cultural consciousness, and carry out effective teaching activities and ideological promotion and education activities in specific courses, which can cultivate students with good moral quality and ideological character, and further improve their ideological level and comprehensive quality. Parents, schools and teachers should work together to realize the integration of family and school 
and carry out effective ideological and political education, so that students can better grasp the advantages and precautions of new media application. Through the close communication with students, it can reflect the better effect of Ideological and political education.

\subsection{Network technology can innovate the working mode of} Ideological and political education in Colleges and universities

With the development of the new media era, new media technology is becoming more and more perfect and innovative, but also more and more recognized and welcomed by students. Teachers can also improve the quality and relevance of educational tools through effective application. The emergence of new media technology is in line with the trend of world development and social development, and can greatly improve the quality and efficiency of Ideological and political education. In this case, teachers need to make full use of new media technology and related tools to constantly improve and innovate the working methods of Ideological and political education, stimulate students' enthusiasm and initiative as far as possible, improve their learning interest and learning initiative, and bring them into the ideological and political education work can produce twice the result with half the effort. Teachers can effectively use wechat's official account or microblog platform and other relevant forms to effectively explain their emotional dynamics or opinions on specific issues. At the same time, combined with specific educational requirements and students' actual learning situation, promote the corresponding ideological and political current affairs hot spots, and pay attention to the content, so that students can timely and effectively understand and master the relevant ideological and political education content. In order to reflect the timeliness and innovation of Ideological and political education, the dynamic of Ideological and political education is synchronized with the content of current events.

\subsection{Fully ensure the effective integration of University} Ideological and political education content and Internet related content

In order to greatly improve the quality of Ideological and political education in Colleges and universities, it is necessary to effectively integrate network resources and ideological and political education content to ensure the organic combination. This reflects the authenticity and diversity of Ideological and political education, which can make students integrate into the society more effectively. In the actual curriculum, it is necessary to actively and effectively select and organize online education resources, further select the relevant content, and ensure that the relevant content is included in the learning process of students.

From the specific training link, to ensure the subjective status of students, so that students can actively and effectively integrate into the society, stimulate the enthusiasm, initiative and independence of students, so as to carry out more effective ideological and political education. In the process of integrating network resources and teaching content, we should guide students to develop good learning habits, make better use of new media skills, strengthen communication, and further broaden the channels of teacher-student interaction. Timely and effective communication, effectively solve students' problems, and then guide students to find the corresponding ideological and political education content on the Internet or in life practice, demonstrate the effectiveness of the combination of theory and practice. In the process of applying new media technology, students' speech is usually unrestricted and can be freely expressed in cyberspace. Teachers can analyze and explore students' speech and behavior in order to find students' shortcomings and use new media methods. Timely and effective guidance and improvement, and then encourage students to make comprehensive progress, effectively improve their expression ability, comprehensive quality and ideological and political level.

\subsection{Improve the ability and quality of all teachers}

The secret of curriculum ideological and political practice lies in Teachers' moral guidance and training ability. First of all, it permeates into ideological, moral and spiritual education as well as the teaching of scientific and cultural knowledge. Second, moral education is not only the professional teachers of horse discipline, but also the infiltration of thought, morality and emotion. Every teacher has established a belief in human education. In the supply organizations related to "curriculum thought", teachers occupy a dominant position and are also the main leaders. However, there are many groups with educational roles in universities, including consultants, Student Department groups and well-known groups. We are trying to create an education model for all staff inside and outside the school, expand the scope of education disciplines, and fully demonstrate the advantages of various disciplines.

In addition to ensuring quantitative and conceptual training for all teachers, the most important thing is to 
improve the quality and ability of training. In particular, it enables the supply agencies to continuously improve the theoretical level and practical effect, not only to spread the correct ideological and political education theory and scientific and cultural knowledge, but also to make students really feel the baptism of thought and moral value. The words and deeds of each educational theme reflect their own moral feelings and educational ideas. The influence of educators on students is not only limited to classroom teaching, but also includes the guidance and demonstration of educational themes. It looks like a mirror effect. In carrying out the education work, we should start from the angle of cultural quality, the angle of Chinese superior traditional culture, the guiding role of modern moral quality and attention to education, and the combination of curriculum education and educational concept. In addition, the theme of education focuses on the methods in the process of educating people, which can be called artistic means.

\section{Conclusion}

In conclusion, in the context of the network environment, in order to better the ideological and political work in Colleges and universities is more complex, we need to innovate working methods, but also need to face the challenges brought by the network information explosion. By improving the ability of Ideological and political education personnel, introducing new media technology, guiding students to reasonably apply new media technology and network technology, it is helpful to carry out the ideological and political work in Colleges and universities.

\section{References}

[1] Zhao CL. Thinking on the combination of Ideological and political work and conscription work in Colleges and Universities under the background of the dream of building a strong army [J]. Modern business industry, 2021, 42(10): 119120.

[2] Liu ZF, Liu M. The negative influence of "information cocoon room" effect on Ideological and political work in Colleges and universities and its breakthrough [J]. Journal of Shandong Youth College of political science, 2021, 37(2): 3542.

[3] Yu YM, Fan Q. Analysis of Ideological and political management of College Students under the network environment $[\mathrm{J}]$. Science and education Wenhui (last ten issues), 2021(3): 29-30.

[4] Feng J. Research on the integration path of college student management and ideological and Political Education [J]. Journal of higher education, 2021(8): 160-163.

[5] Huang SS. Exploration on the theory and practice of "curriculum ideological and political education" in Universities of science and engineering [N]. Tianjin daily, 2021-03-06 (15).

[6] Li R. Research on the application of Ideological and political work of college students based on E-class platform [J]. Digital world, 2021(3): 199-200.

[7] Li J. Micro and taste: A systematic exploration of comprehensively promoting the ideological and political construction of curriculum[J]. Beijing Education (moral education), 2021(2): 29-32 + 37 . 